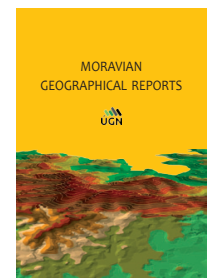

\title{
From the agricultural station to a luxury village? Changing and ambiguous everyday practices in the suburb of Vinnytsia (Ukraine)
}

\author{
Oleksiy GNATIUK ${ }^{\text {a }}$, Kostyantyn MEZENTSEV a ${ }^{\text {, Nataliia PROVOTAR }}{ }^{\text {a }}$
}

\begin{abstract}
The study of everyday practices, self-identities and perceptions seems to be a promising approach to understand the suburban spaces as not only static containers but socially constructed, dynamic and ambiguous entities. Our case study is represented by the suburban village of Ahronomichne, located in the peri-urban area of the second-order Ukrainian city of Vinnytsia. The research methods included survey of residents (67 longterm residents and 59 newcomers), observations of the everyday activities of the residents and appearance of the build environment at seven observation points within the village, and four semi-structured in-depth interviews. We found that everyday practices of the long-term residents and newcomers significantly differ in terms of their set, spatial configuration and actual exercitation. The other important factors contributing to the variety of everyday practices and lifestyles are type of housing, age and family status. Simultaneously, we observed not just a combination but rather intertwining, mixing and hybridisation of urban, suburban and rural everyday practices and lifestyles. Another finding of the research was the western-type suburban growth of the second-order Ukrainian city in contrast to the largest cities of the country where centrifugal migrations of rich people to peri-urban area combines with the centripetal stream of less affluent migrant from peripheral settlements, keeping transitory residential strategy.
\end{abstract}

Keywords: suburbanisation, everyday practices, lifestyles, Vinnytsia, Ukraine

Article history: Received 25 February 2021, Accepted 29 July 2021, Published 30 September 2021

\section{Introduction}

We live in the (questioned) "age of urbanisation", under conditions of dramatic wave of urban restructuring (Brenner and Schmid, 2014, 2015), and this is an indisputable argument why urban processes and phenomena deserve special attention, especially from geographers. However, in the context of planetary urbanisation (Brenner and Schmid, 2015), the "urban question" can well be described as a "suburban question" (Phelps, Tarazona Vento and Roitman, 2015; Phelps, 2017; Keil, 2018), and the current epoch - as the suburban century (Schneider, 1992). The point is that cities in different parts of the world are largely growing by their suburbs: both urban and suburban populations are growing in the global scale.

Since the second half of the 1990s, suburbanisation has been one of the most important processes that influenced the transformation of the settlement patterns in the post-socialist countries of the Central and Eastern Europe (hereinafter CEE)
(Borén and Gentile, 2007). At the same time, post-socialist cities hold a specific place in conceptualising the suburban development given the unique trajectory of peri-urban areas in post-socialism (Ouředníček, 2007; Stanilov and Sýkora, 2014) comparing to the "western-type" suburbanisation.

The main aspects of the western-type suburbanisation are widely discussed regarding their possible manifestation in the post-socialist space (e.g. Hirt, 2007; Tammaru, 2001; Slaev and Kovachev, 2014; Krisjane and Berzins, 2012). We share Hirt's vision that some aspects are most pronounced, namely locational, motivational, functional and demographical:

- Locational: new inhabitants of the classical western-type suburbia come mainly from the urban core or from other urban areas;

- Motivational: migrants are driven by environmental considerations - to escape urban life disadvantages,

\footnotetext{
${ }^{a}$ Department of Economic and Social Geography, Faculty of Geography, Taras Shevchenko National University of Kyiv, Kyiv, Ukraine (*corresponding author: O. Gnatiuk, e-mail: alexgnat22@ukr.net)
} 
and find a higher-quality and more "family-oriented" lifestyle in greener, more private, and socially exclusive settings (including the desire to own a detached house).

- Functional: suburbs are typically residential zones that substantially depend on the central city in terms of jobs, which results in increased commuting; borders between urban and rural areas are blurred due to the spread of low-density detached housing.

- Demographic: suburban development is related to the people's life-cycle stages and is initially led by upper-and upper-middle-income actors that are typically affluent and well educated.

Suburbanisation in the $\mathrm{CEE}$ large cities has aspects of western type suburbanisation, e.g. in Estonia (Tammaru, 2001; Tammaru and Leetmaa, 2007), Latvia (Krisjane and Berzins, 2012), Bulgaria (Hirt, 2007; Slaev and Kovachev, 2014). At the same time, local contribution to classical model is emphasised, in particular: new suburbs of large post-socialist cities are more compact, with higher densities and higher levels of social mix and mix of uses (Slaev and Kovachev, 2014). Moreover, western type suburbanisation is hindered by an insufficient number of jobs in the suburbs, poor road and social infrastructure, and low living standards (Nefedova, 2018). Thus, simplified model of the "western-type suburbanisation" cannot adequately explain the post-socialist changes in housing suburbanisation (Leetmaa, Tammaru and Anniste, 2009, p. 437).

Similar to the other post-socialist countries, peri-urban development in Ukraine does not correspond to the classical model of western-type suburbanisation, when affluent city dwellers move to the peri-urban area to live in environmentally and socially safer conditions. On the other hand, it cannot be aligned with the reversed western-type suburban development, when the low-income population moves to the suburban area in order to implement a survival strategy (Mezentsev, 2017). Also, there are discussions on the feasibility of the classic indicators of suburbanisation, e.g. higher population growth rate in the peri-urban area compared to the big city (Mezentsev, 2017). Speaking more broadly, there are debates about the correspondence of the urban development in Ukraine to the stages of urban development model (van den Berg et al., 1982; Cheshire and Hay, 1989; van den Berg, 1999) and differential urbanisation model (Geyer and Kontuly, 1993). In particular, it was shown that despite some common trends and apparent similarity to the urban development in the western world, stages of urban evolution and migration patterns in Ukraine are rather debatable and may essentially differ from the provisions of the mainstream theory (Mezentsev and Havryliuk, 2015; Malchykova and Pylypenko, 2017; Gnatiuk, 2018; Havryliuk et al., 2021). In fact, post-socialist peri-urban development may include a combination of several typical scenarios or processes depending on the social profile, place of origin and work of migrants, their motivation (Ford, 1999; Fisher, 2003; Hirt, 2007; Ouředníček, 2007).

The regional and national diversities of suburban development (including specific post-socialist trajectories) are supplemented with the growing diversity of suburbia itself. Since the 1970s, the researchers have emphasised its increasing diversity and erosion of hallmarks, so called "maturing" of suburbia, diversification of land use patterns and functions (McManus and Ethington, 2007; Harris, 2010), the emergence of its own centres and forms of economic activity, and, as a consequence, the growing independence of the suburban area from the central city (Massotti, 1973; Garreau, 1991; Golubchikov, Phelps and Makhrova, 2010; Manshylina, 2015). As a result, suburbia loses its homogeneity: although individual regions and cities tend to produce specific types of suburban areas, different types of suburbia often coexist in the same area, mixing different land uses, building types, social strata and social practices (Shen and Wu, 2013; Drummond and Labbé, 2013; Phelps, 2017; Keil, 2018). Moreover, the traditional understanding of the city-countryside dichotomy is replaced by the concept of urban-rural continuum, so called post-suburbia, with attractive residential areas, new infrastructure in trade and services, employment opportunities mainly in the tertiary sector and industry, high personal mobility and, the most important, a new lifestyle that cannot be described via the "old" categories of urban and rural (Borsdorf, 2004; Mezentsev, 2017). In particular, post-socialist transitions have led to the exposure of the countryside to global flows and hence to the blurring and partial collapse of spatial categories such as "centre-periphery" and "urban-rural" (Duijzings, 2013).

Suburbia can be studied from different points of view: migration, relocation and redistribution of population; population and housing growth; change in the population structure (by incomes, education, age, etc.); decentralisation of economic activity and employment. The main alternative approaches for the typology of suburban spaces and settlements are statistical, morphological and genetic (Mantey and Sudra, 2018). However, these methods are not always able to fully characterise the substantial aspects of peri-urban development in the conditions of diversifying and "maturing" suburbia. In order to fully understand the suburban spaces, it is necessary to study them via the lens of everyday life of local inhabitants. At the same time, suburban spaces are not just "containers" where the everyday life of residents takes place, but the living environments that influence the behaviour of people and provide senses (Eyles, 1989; Mezentsev et al., 2019).

Combining the given perspectives, we have posed the following research goals: (1) to conceptualise the scenario of suburban development for the second-order post-socialist city in terms of the origin and motivation of residents, within the existing theoretical framework on the urban evolution in general (e.g. van den Berg, 1982; Cheshire and Hay, 1989) and overall peri-urban development patterns in particular (e.g. Ford,1999; Fisher, 2003; Hirt, 2007; Ouředníček, 2007; etc.), and (2) to describe the suburban development with respect to changing everyday practices and respective lifestyles in the context of social differentiation of residents (Walker and Li, 2007; Provotar et al., 2019; Mezentsev et. al., 2019, 2020).

\section{Changing suburban spaces through the lens of everyday practices}

The study of the routine, mundane aspects of traditional human geography subjects may reveal some of their essential but still hidden details (Denysyk et al., 2020). From this point of view, the study of lifestyle in terms of various everyday practices of suburban residents is an important aspect of studying suburban spaces and understanding their transformation. Moreover, in order to better understand and conceptualise the suburban way of life, it is necessary to explore how local residents themselves understand, perceive and interpret the suburbia, what they think and say 
about it (Harris, 2010). The specificity of everyday practices in the suburban spaces stems from their social nature (Bourne, 1996), they begin with physical characteristics but are not limited to them (Harris, 2010). Suburbia is socially "developed" to achieve certain collective and individual goals (Bourne, 1996). The main social characteristics are usually related to the level of income, ethnic structure, migration behaviour, and lifestyle.

The meaning of the term "lifestyle" is rather ambiguous, as there are a range of definitions, depending on the academic field (Pisman, Allaert and Lombaerde, 2011). The term is used with regard to behaviour (e.g. choice, acquisition, use, and consumption), behavioural domains (e.g. dwelling, work, transport) and factors that influence behaviour (e.g. intentions, preferences, values or structural variables) (Heijs et al., 2009; Pisman, Allaert and Lombaerde, 2011). As people often make their residential choices basing on keeping their habitual everyday practices, the spatial division of lifestyle groups in different neighbourhoods is considered to be one of the most important spatial impacts of lifestyles (Aero, 2006; Feijten et al. 2008; Mokhtarian and Cao, 2008; van Acker, 2010; Jansen, 2020).

The differences and, simultaneously, ambiguous relationships between urban, suburban and rural lifestyles have been pointed out since the middle of the XX century (e.g. Amato, 1993; Le Gates and Stout, 1996; den Hartog, 2006; Aero, 2006; Kaneff, 2013; Matz, Stieb and Brion, 2015; Jansen, 2020). The term "suburbanism" was first proposed in the 1950 s as a "third way" between the concepts of urbanism and ruralism, as a specific sociopsychological state and pattern - a suburban way of life (Fava, 1956). Specific patterns of everyday practices of suburban residents are determined mainly by the high level of their everyday mobility, which affects, first of all, the practices of working, consumption, recreation and leisure (Mezentsev et al., 2019). However, although it is widely accepted that urban and suburban lifestyles differ from each other (Pisman, Allaert and Lombaerde, 2011), nowadays it is almost impossible to talk about typical lifestyle and everyday practices in the suburbs as it was at the global start of suburban growth. Suburban spaces are characterised by double diversity: on the one hand, in terms of development type and composition of residents, and on the other, in terms of a set of everyday practices (Mezentsev et al., 2020). Suburbia is becoming a place where different forms and practices mix, where low-rise detached houses and multi-storey residential complexes are located next to each other, where rich, middle class and poorer inhabitants often live in spatial proximity, where ideas about "feminised suburbia" and "masculinised" city are blurred (Drummond and Labbé, 2013). Suburban residents may have different lifestyles referring to their economic and socio-cultural capital, housing history and their functional, social and emotional relationship with residential environment (Reijndorp et al., 1998; Reijndorp, 2004) and residential strategies, i.e. long-term inhabitants and transit riders (Walker and Li, 2007; Mezentsev et al., 2020).

In today's globalised world, urban lifestyles are perceived as modern and attractive, they are mostly sought to be adopted and copied, and thus their elements are gradually becoming part of the mundane life for residents of other areas. As Davidson and Lees (2005, p. 1167) put it, "the urban-rural dichotomy has broken down, as a significant part of the world has become increasingly urbanised and desirous of an urban lifestyle". The everyday practices of the inhabitants of the suburban zone are "urbanising" and become much less dependent (or completely independent) from the central city (Anderson, 2006; McManus and Ethington, 2007). In such circumstances, the boundary between the city and the suburban area looks quite formal; often it is even difficult to delineate the margin between the urban and suburban space (Dymitrow and Stenseke, 2016). Each of the suburban evolution options (decline of cities in favour of suburbia; transformation of suburbia into postsuburbia; transformation of post-suburbia into cities; decline of suburbia and its transformation into "something less than suburbia") (Phelps, Tarazona Vento and Roitman, 2015) is accompanied by specific changes in everyday practices. However, despite the long-term intense influence of large cities on their suburban areas, some "old" suburban and even rural practices can still be identified. The general trend of recent years is the overlapping and hybridisation

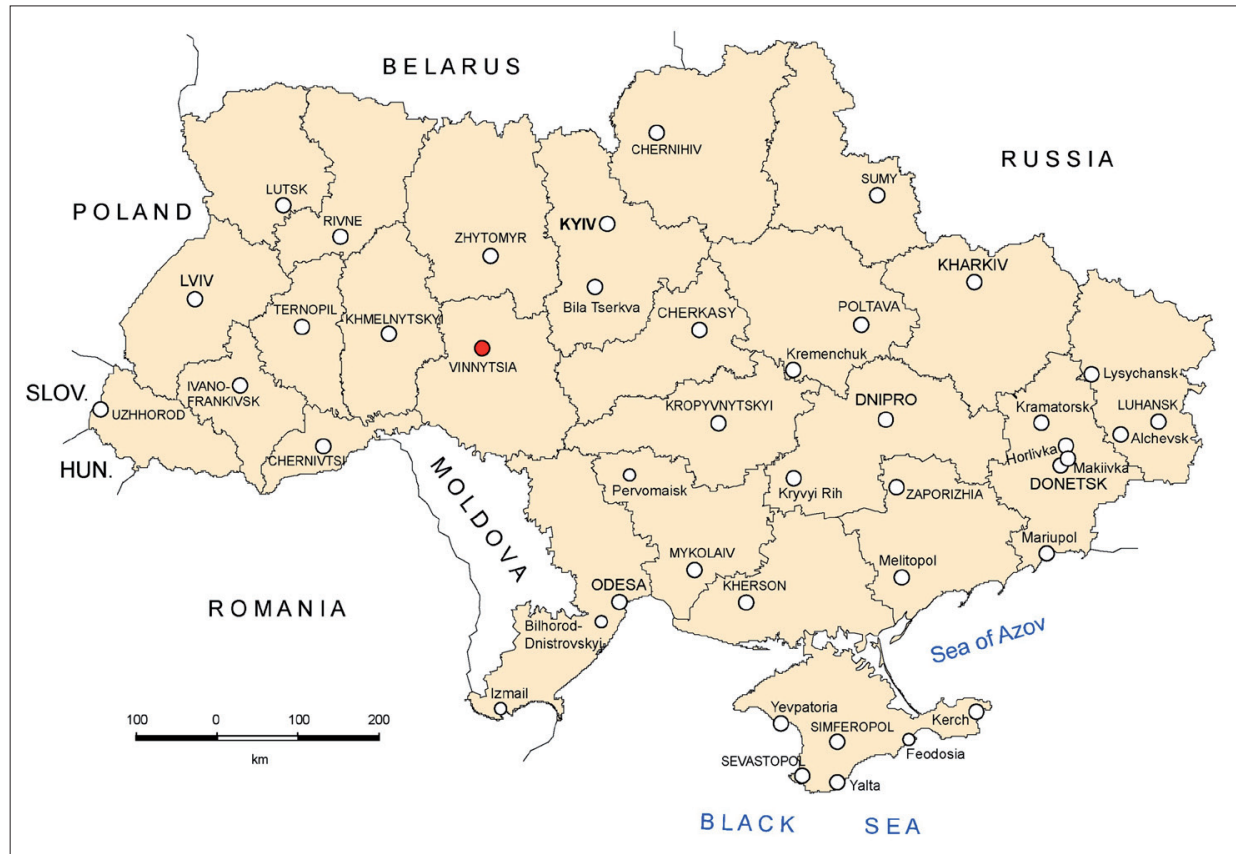

Fig. 1: Location of Vinnytsia 
of typically urban, suburban and rural everyday practices in suburbia (Mezentsev and Provotar, 2020; Mezentsev et al., 2020). Different spaces are thus filled with different levels and forms of suburbanism (Walks, 2013).

\section{Case study area}

This study is focused on the second-order Ukrainian city of Vinnytsia with current population ca. 370,000 (Fig. 1). The overwhelming share of literature on suburban development in the post-socialist countries is devoted to the large metropolises, and only a few publications reveal the peculiarities of second-order cities (e.g. Matlovič and Sedláková, 2007; Gnatiuk, 2016; Zakutynska and Slyvka, 2016; Kubeš and Nováček, 2019). During the last decades, Vinnytsia demonstrates a pronounced outpacing population growth of the peri-urban area alongside the stagnating or even declining population of the city itself (Gnatiuk, 2017). The average radius of the area affected by suburban processes is approximately $25 \mathrm{~km}$; however, its shape is characterised by spatial asymmetry due to the factors like different aesthetic appeal of landscapes, differences in the functional profile of the individual parts of the central city, configuration of main transport arteries and allocation of the neighbouring small cities. Especially high rates of suburban growth are observed in the south-western and western sectors (Gnatiuk, 2016).

The village of Ahronomichne, selected for our case study, is located on the south-western outskirts of Vinnytsia (Fig. 2). Comparing to the typical villages in the region, it is very young settlement founded in 1965 for the agricultural research station that moved from the other village to the outskirts of the city. The specific function of the settlement was imprinted in the visual appearance and the nature of residential development, namely the presence of apartment houses and dormitories constructed for the research station employees in the 1960-1980s. Since the 1990s, the research station is experiencing a period of decline and has ceased to be a major employer for residents although officially it continues to operate as a unit of the National Academy of Agrarian Sciences of Ukraine.

Considering the proximity to the city and favourable landscapes, Ahronomichne became a subject to suburban growth starting from the $2000 \mathrm{~s}$. The village demonstrates one of the fastest rates of population growth among the peri-urban settlements. In 2018, the registered population was 3,852 inhabitants, and it is projected that in 2030 the population will reach 15,000 . Recent residential development of the village demonstrates significant morphological heterogeneity: detached houses neighbour upon multi-storey apartment houses, as well as cottage towns and townhouses, some of the latter being gated or semi-gated communities (Fig. 3).

According to the urban planning and strategic documents of the 2010s, the spatial development of Vinnytsia should have been implemented in accordance with the concept of a compact city. Therefore, the expansion of the city limits via absorption of the adjacent rural settlements was not planned. However, in 2015, under extremely favourable political situation (the former city mayor Volodymyr Groisman acted as a Ukrainian Prime Minister), the limits of the city were expanded, including absorption of a proximate part of Ahronomichne built-up with detached houses of local new rich, so called Tsarske Selo (literally "Tsar Village"). In 2019, in course of the administrativeterritorial reform in Ukraine, the village community decided between joining the Vinnytsia urban community and creating a separate rural community. Despite the close ties with the city, the discussions and rallies were finally won by the opponents of absorption; their key arguments were higher land taxes and utility fees in the city, as well as

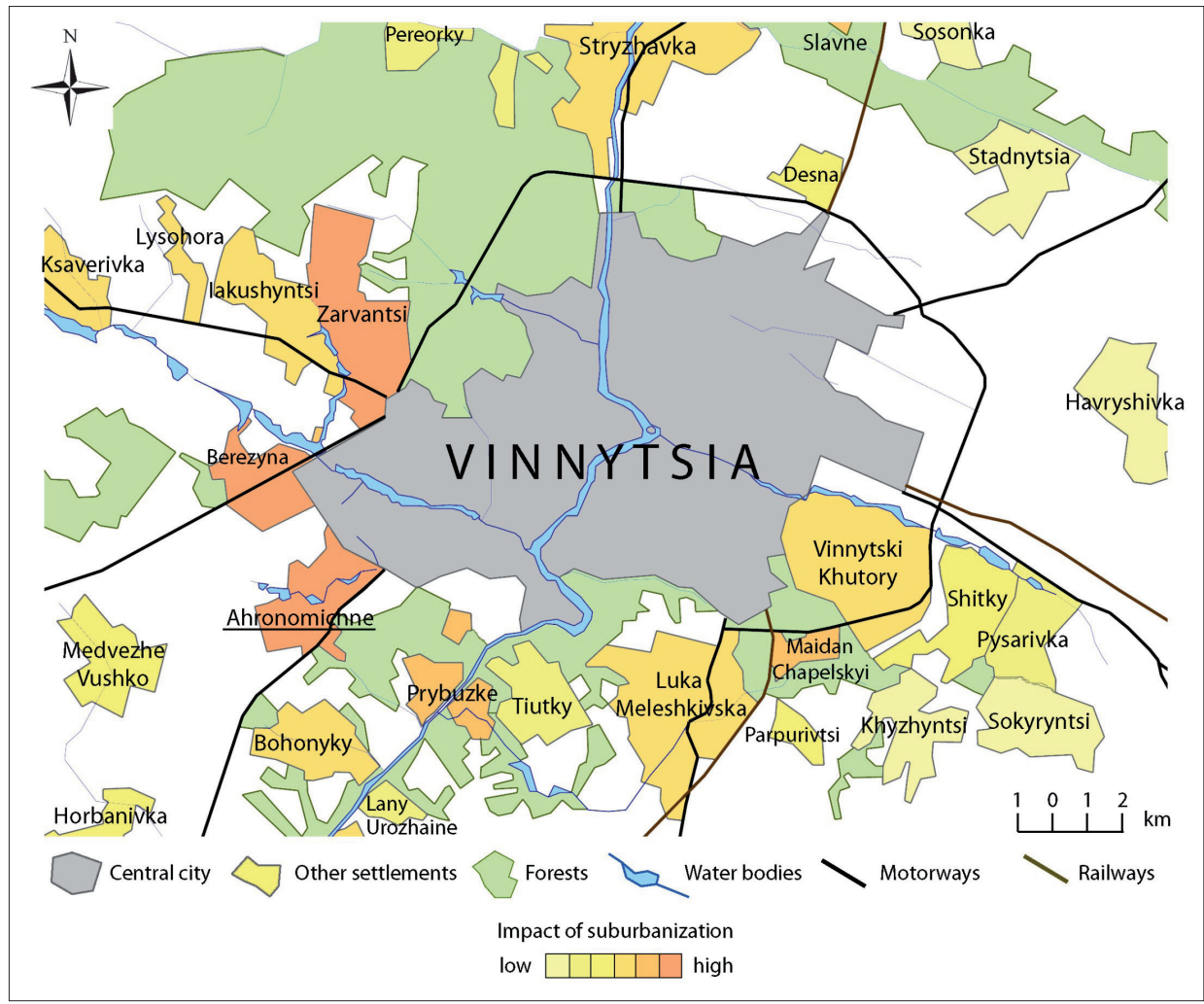

Fig. 2: Position of Ahronomichne in the suburban area of Vinnytsia

Source: authors' elaboration. The assessment of the suburbanisation impact according to Gnatiuk (2016) 


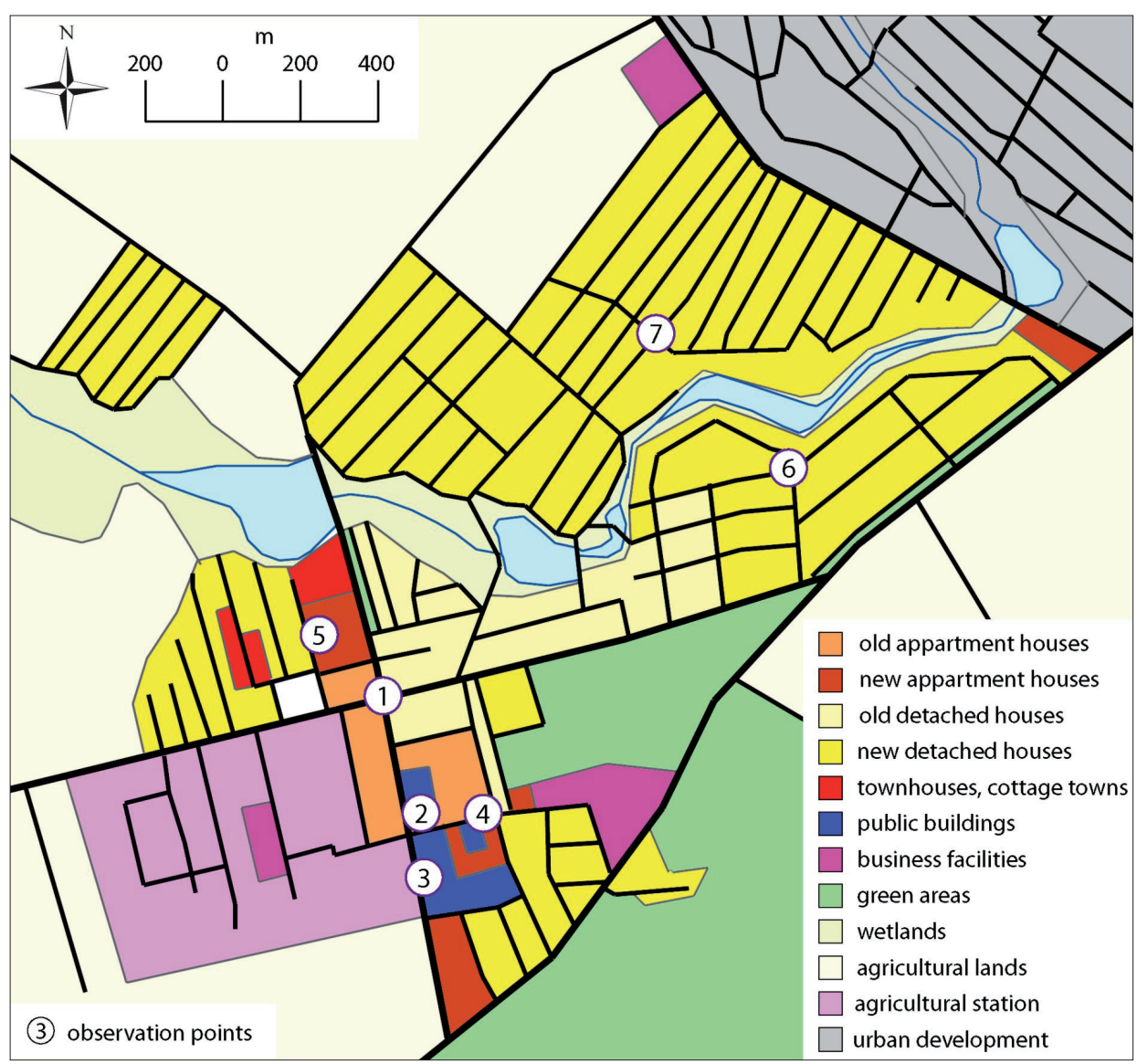

Fig. 3: Morphological and functional zoning of Ahronomichne and position of observation points Source: authors' elaboration

fears that the village may not have own representative in the City Council. Consequently, since 2020, Ahronomichne became a centre of a village community that includes also several other suburban villages (Bokhonyky, Medvezhe Vushko, Horbanivka, Ilkivka, Rivets - see Fig. 2), and joining the city in the short term is not being discussed. However, recent heated debates about the future of the village could exacerbate the contradictions between the long-term residents and newcomers.

\section{Data and methods}

Suburbanisation processes in Ukraine are quite uneven: they depend on the region and the suburbanisation potential of the city (Mezentsev and Mezentseva, 2017; Gnatiuk, 2017). In particular, five main types of suburban spaces with specific types of housing and lifestyles can be distinguished: suburban-absorbed rural settlements, new "cottage" villages, residentialised summer houses settlements, amplified Soviet-era satellite towns and "internally" suburbanised neighbourhoods within the cities (Mezentsev et al., 2019). The internal diversity of Ukrainian suburban areas is shaped by the overlapping lifestyles of urban and rural residents (Zakutynska and Slyvka, 2016), migrants from different regions, "temporary" residents who implement a conscious or forced transitional or long-term strategy (Mezentsev et al., 2019). Differences in everyday practices and lifestyles of long-term residents and newcomers are caused by differences in their origin, as well as social and property status (Mezentsev et al., 2020). Typical urban residents in Ukraine, especially in big cities, are living in high-rise apartment houses, have no personal homesteading and thus depend on jobs in services or industry. In the recent decades, they benefit from the intense development of catering, entertainment and leisure industry, and are used to spend free time visiting public spaces like shopping malls or street cafes. On the contrary, rural residents in Ukraine typically live in detached houses, are employed in agricultural sector and usually have homesteading both as a part of rural tradition and a matter of survival. The services available are typically limited to the old-fashioned food store, second-rate cafe and beat-up community club, and thus their lives are more monotonous and tied to the own homesteading (Hukalova, 2009). At the same time, rural residents are used to keep closer social ties comparing to their urban counterparts. In Ukraine, the urban lifestyle is seen as more attractive, as it is characterised by the dynamism of socio-economic transformations, a more diverse cultural environment, a variety of lifestyles, a high level of social mobility. However, this does not apply to the way of life in small towns, where it is mainly similar to the rural one.

Thus, the employed research methodology should be able to show the similarities and differences of the everyday practices, identities and perceptions (1) in the dichotomy of old-term residents and the recent newcomers, (2) in the dichotomy of the residents of apartment houses and detached houses (as well as townhouses and cottage settlements). Given the actual start of residential suburbanisation in Ukraine in the late 2000s (Mezentsev and Mezentseva, 2017), the time of living in suburbia may be considered as a main criterion to distinguish between the long-term rural residents and newcomers. In view of the foregoing, the research methodology employed three methods, each focused on the specific aspect of the investigated issue although partly overlapping and complementing each other (Fig. 4). 


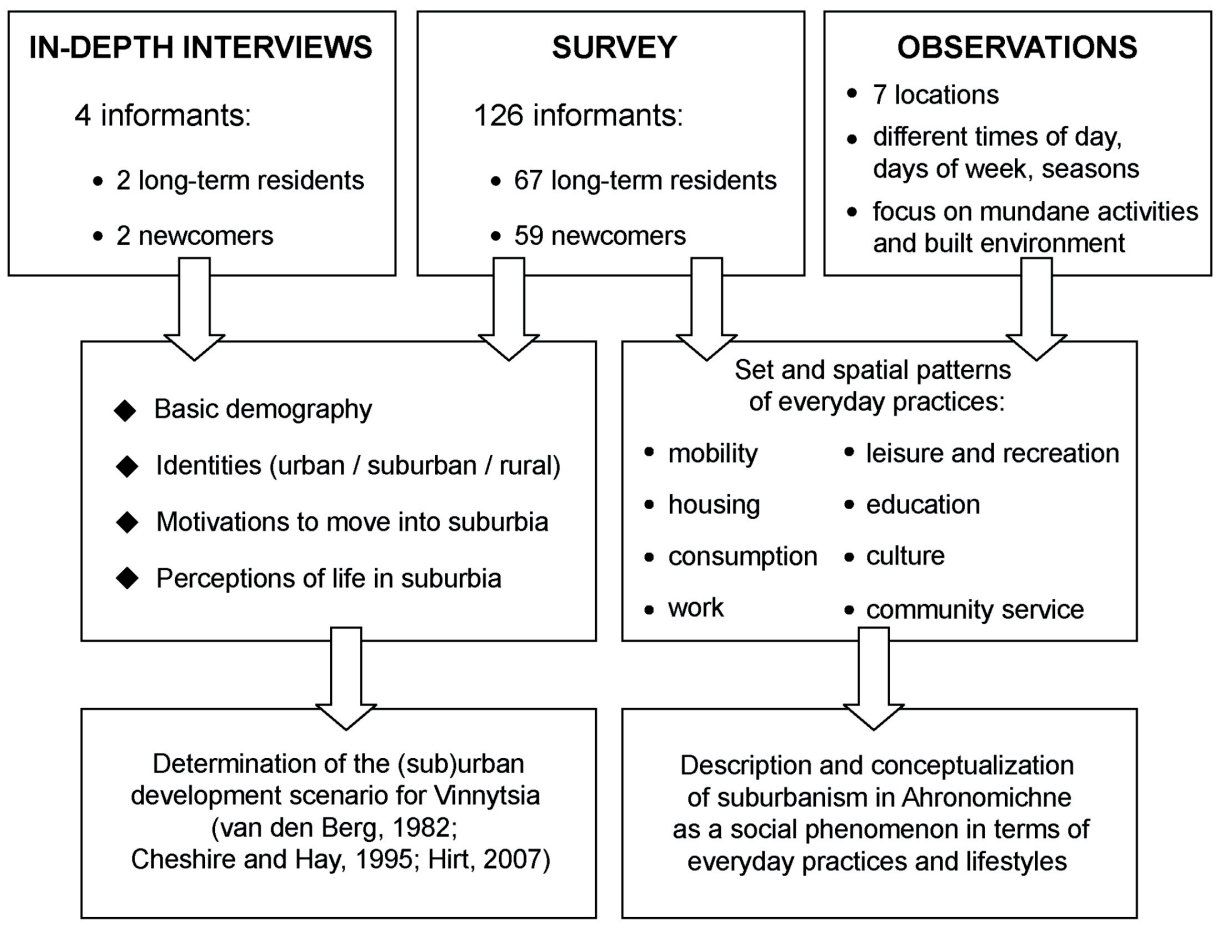

Fig. 4: Scheme of the research methods and goals Source: authors' elaboration

The main research method was a survey of residents carried out in July-August 2020 and December 2020 January 2021. The survey was conducted among a random sample of Ahronomichne residents catch by the interviewer in the public spaces of the village and near their homes. The informants $(n=126)$ were divided into two groups: longterm residents (those living in Ahronomichne for 10 years or more; 67 informants) and newcomers (those living in Ahronomichne for less than 10 years; 59 informants). The key subject of the analysis were the most common forms of everyday practices such as mobility, housing, consumption, work, leisure and recreation, education and cultural development, community service, including selforganisation at the suburban community level (Mezentsev et al., 2019). Despite the relatively small number of survey subjects, the sample size was sufficient to show some statistical significance and there is no theoretical reason to expect that a larger sample would lead to very different results. Moreover, similar sample sizes are not uncommon (e.g. Ghose, 2004; Hirt, 2007). We used Pearson's Chi-Square test to evaluate cross-tabulations, and in the most cases null hypothesis of insignificant difference between the behaviour of long-term residence and newcomers were rejected.

Additional source of information about the everyday practices (as well as about the built environment of the village) were visual observations of the mundane activity of the residents, performed in October-November 2019, AprilMay 2020 and January 2021 at seven basic locations (Fig. 3):

- 1 - intersection of the two main streets;

- 2 - square and playground in the village centre;

- 3 - square near a school and a village hall;

- 4 and 5 - new residential complexes (apartment houses);

- 6 and 7 -crossroads in the areas of new detached housing.

Locations were selected in order to (a) cover both old and new parts of the village and (b) observe everyday practices of housing, mobility, leisure, recreation, shopping, etc.
Observations were carried out on weekends and weekdays, as well as in the morning, afternoon and evening hours. Also, in-depth semi-structured interviews with two newcomers and two long-term residents were taken in order to clarify the perception of living in transforming suburbia by suburban residents. In the following section, questionnaires and interviews of the long-term residents are marked as "LTR", of the newcomers - as "NC", respectively.

There are several circumstances that may influence the integrity of the study. The first is already mentioned relatively small sample size: the use of the larger sample for the survey and a larger set of in-depth interviews would allow drawing more confident conclusions about the similarities and/or differences between the subgroups of informants. The second is a lack of accurate and detailed information on the demographic structure of the sampled population, in particular, the exact age and sex structure, as well as proportion between the long-term residents and newcomers, which may influence the overall conclusions of the balances of lifestyles in Ahronomiche. The third is probable selection bias due to the difficulty of reaching informants from the gated communities/households. However, these limitations seem to be not crucial for the key findings and their interpretation.

\section{Results and discussion}

The basic characteristics of the survey informants, including their origin, mobility, motivation for migration, occupation and economic activity, self-identification, perceptions, social communication and composition of the homesteading are presented in Table 1, while Table 2 shows spatial configuration of the studied everyday practices.

Three findings are made based on the results of the survey, interviews and observations. The first one is the dominance of western-type pattern of peri-urban growth of Vinnytsia's suburbia. The second one claims that nowadays the suburbia is divided in terms of everyday practices, self-identifications and perceptions of the long-term residents and newcomers. 


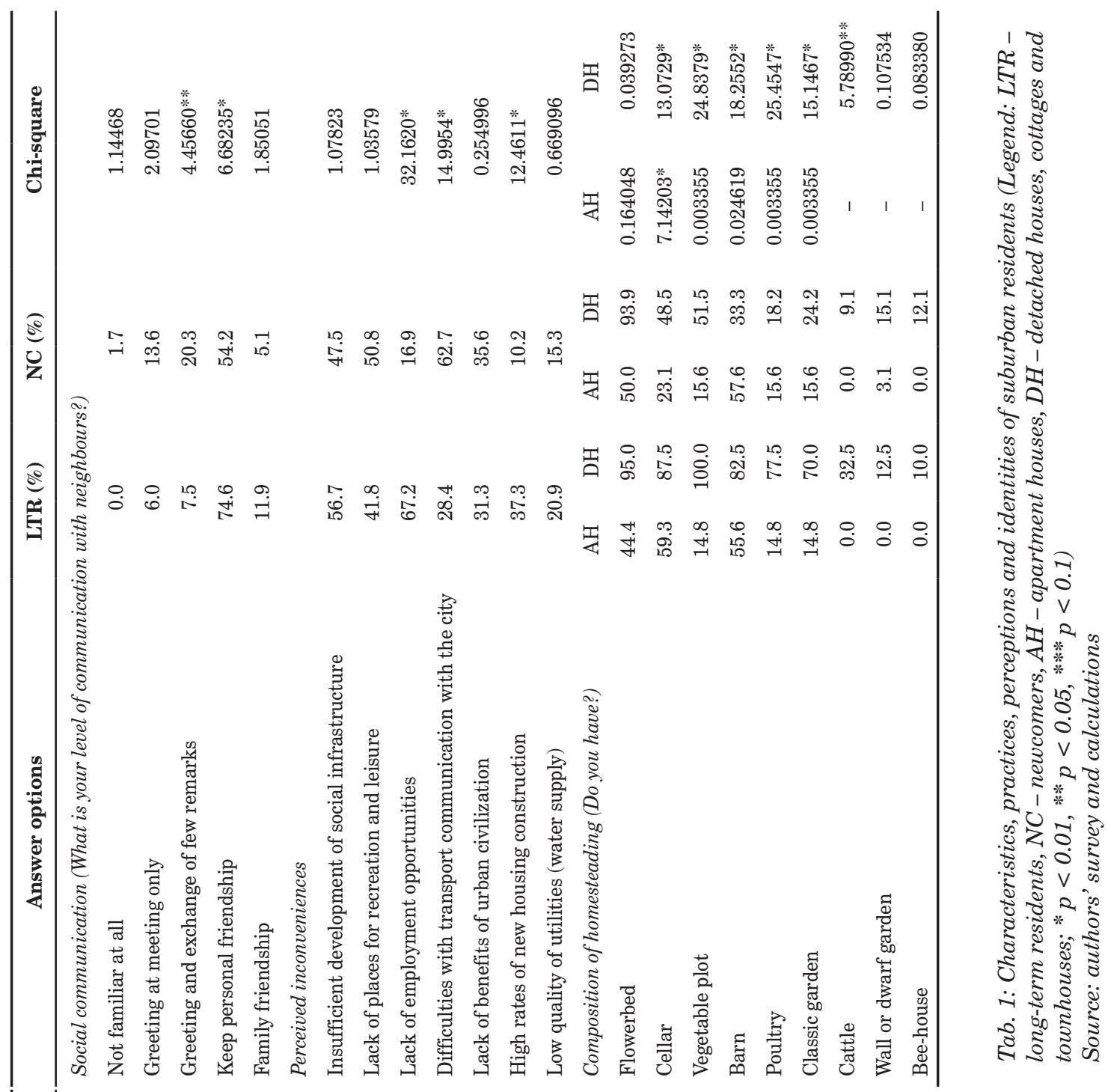

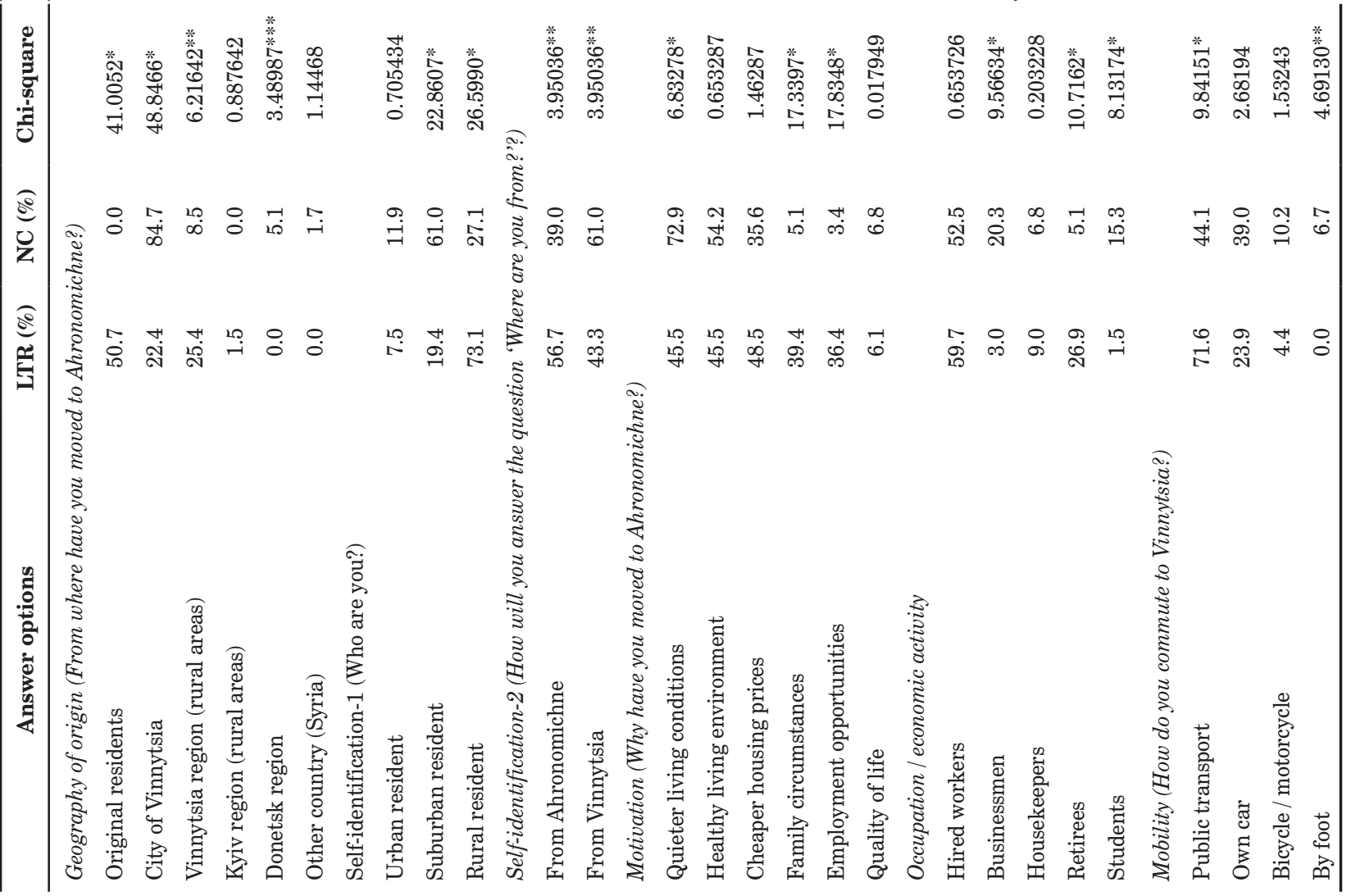




\begin{tabular}{|c|c|c|c|c|c|c|c|c|}
\hline \multirow[b]{2}{*}{ Everyday practices } & \multicolumn{4}{|c|}{ Long-term residents } & \multicolumn{4}{|c|}{ Newcomers } \\
\hline & $\begin{array}{c}\text { Suburbs } \\
\text { only }\end{array}$ & $\begin{array}{l}\text { Suburbs } \\
\text { and city }\end{array}$ & City only & No activity & $\begin{array}{l}\text { Suburbs } \\
\text { only }\end{array}$ & $\begin{array}{l}\text { Suburbs } \\
\text { and city }\end{array}$ & City only & No activity \\
\hline Work or education & 28.4 & 6.0 & 29.9 & 35.8 & 10.2 & 5.1 & 72.9 & 11.9 \\
\hline Purchase of food products & 23.9 & 59.7 & 16.4 & 0.0 & 16.9 & 39.0 & 44.1 & .0 \\
\hline Purchase of non-food products & 16.4 & 35.8 & 47.8 & 0.0 & 5.1 & 22.0 & 67.8 & 5.1 \\
\hline Leisure, entertainment & 40.3 & 28.4 & 17.9 & 13.4 & 5.1 & 25.4 & 55.9 & 13.6 \\
\hline Time with friends & 49.3 & 35.8 & 7.5 & 7.5 & 49.2 & 27.1 & 11.9 & 11.9 \\
\hline Doing sports & 19.4 & 16.4 & 7.5 & 56.7 & 44.1 & 5.1 & 16.9 & 33.9 \\
\hline Visiting catering facilities & 7.5 & 23.9 & 19.4 & 49.3 & 0.0 & 6.8 & 62.7 & 30.5 \\
\hline Visiting cultural institutions & 19.4 & 16.4 & 31.3 & 32.8 & 0.0 & 5.1 & 76.3 & 18.6 \\
\hline Visiting beauty industry & 28.4 & 28.4 & 23.9 & 19.4 & 5.1 & 5.1 & 71.2 & 18.6 \\
\hline Medical care & 11.9 & 5.1 & 73.1 & 10.4 & 0.0 & 0.0 & 94.9 & 5.1 \\
\hline Education of children & 28.4 & 7.5 & 22.4 & 41.8 & 27.1 & 11.9 & 39.0 & 22.0 \\
\hline Leisure with children & 35.8 & 28.4 & 5.1 & 31.3 & 39.0 & 11.9 & 27.1 & 22.0 \\
\hline Civic activity & 35.8 & 9.0 & 10.4 & 44.8 & 20.3 & 11.9 & 6.8 & 61.0 \\
\hline
\end{tabular}

Tab. 2: Spatial configuration of everyday practices for long-term residents and newcomers Source: Survey and calculations by the authors

The third one is about mixing and hybridisation (rather than replacement) of urban, suburban and rural everyday practices and lifestyles. The following subsections are discussing these aspects in more detail.

\subsection{Western-type pattern of peri-urban growth}

The results show that the western-type pattern of suburban growth prevail in Ahronomichne. First, the majority of newcomers are former urban residents, and most part of them moved from Vinnytsia, the central city. Thus, we observe centrifugal migration pattern, which is classical for westerntype suburban growth. Furthermore, upon the average, the newcomers are more affluent comparing to the long-term residents and have higher social status (significantly higher shares of businessmen and lower share of retirees among the newcomers), and their main motivations for moving to suburbia were quieter living conditions and healthier living environment, which fits the broader idea of urban escape (Hirt, 2007). On the contrast, factors like cheaper housing prices, family circumstances and employment opportunities were much more often mentioned by the long-term residents. The other hallmarks of the western-type suburban growth are high dependence on personal car for commuting and strong dependence on the city in everyday life, which is evident from the Table 2. The idea of urban escape was articulated by the interviewed newcomers as well:

"The quality of life here is completely different. There is silence, peace; there is no city bustle to which you get used, but which kills all the joy of life ... the opportunity to have your own piece of land. Look here - a flowerbed, strawberries, bushes... You live in four walls [in the city], and you want to have a piece of nature. Here you want to go to the field - here is a field. If you want to go to the forest here is a forest. No gray walls covering the sky. And what is the sky like here... Did you see the sky here at night? You will never see this in the city. I'm willing to pay extra for this." (Informant NC-01)

Therefore, in terms of peri-urban development concepts, the peri-urban growth of Vinnytsia could be classified as suburbanisation (migration from the central city to the nearest peri-urban belt) (Ford, 1999; Fisher, 2003), westerntype suburbanisation (relocation of wealthy households from the central city to the countryside) (Hirt, 2007), centrifugal migration from the central city to the periurban area, predominantly to the newly-built housing (Ouředníček, 2007). However, cheaper housing prices in suburbia were important for $35.6 \%$ of newcomers, and $27.1 \%$ of them declared mixed motivation: ecological (urban escape) together with economical (cheaper housing). This indicates that the stream of migrants to suburbia is not homogenous: wealthy migrants are accompanied by people with relatively low incomes, although this can hardly be called a genuine desurbanisation (Hirt, 2007).

Interestingly, in terms of peri-urban growth pattern, the suburbs of Vinnytsia are qualitatively different from the suburban area of a big Ukrainian city like Kyiv, where centrifugal migrations of rich people to peri-urban area combines with the centripetal stream of less affluent migrant from peripheral settlements, keeping transitory residential strategy (Mezentsev et al., 2019, 2020).

\subsection{Divided suburbia in terms of everyday practices, self-identification and perception}

Long-term residents and newcomers demonstrate essentially different patterns of their everyday practices in terms of (1) set of practices, (2) their spatial configuration and (3) mode of their performance. Also, the differences are observed in (4) self-identification and perception of life in suburbia.

Differences in the set of practices are due to different geography of origin of the long-term residents (who often indicated the absence of practices related to sports, catering, leisure and entertainment) and newcomers. The former are predominantly descendants from rural areas, who spent in villages all their lives and firmly mastered the rural way of life. They prefer physical activity in the garden to sports and fitness, and they often have no time, money and desire to visit, for example restaurant, theatre or night club. On the contrary, newcomers, who brought with them urban habit and want to follow the familiar way of life, consider such 
practices like going to the gym or visiting a café with friends as must-have things. They meet these needs mainly in the city that causes significantly higher mobility (commuting) of the newcomers. At average, the long-term residents are older than newcomers and thus have no necessity to spend much time with children or educate them. Also, while the longterm residents keep interpersonal communication practices typical for the close-knit community, the newcomers are much less eager to establish strong social contact with their neighbours in suburbia. The practices of housing are also a remarkable point: presence of a vegetable plot, cellar, barn, poultry, and garden is almost mandatory for detached houses of long-term residents, but only optional for the similar houses of newcomers. These practices of homesteading have different meaning for the long-term residents and newcomers: for the former they are a means of economic survival, but for the latter they are just for amusement and following the fashion.

Differences in the spatial configuration of everyday practices consist in significantly higher dependence of the newcomers on the central city. This main reason is the desire of the newcomers to continue enjoying the benefits of "urban civilisation" and keep urban lifestyle. The most remarkable differences relate to leisure and entertainment and education of children: while long-term residents have these practices in suburbia, the newcomers shift them to the city. Significant differences are observed also for visiting catering services, cultural institutions, beauty industry, and purchase of food, education and work. The less remarkable differences are observed for time with friends, doing sports, leisure with children and civic activity (concentrated more in suburbia than in the city), purchase of non-food products and medical care (concentrated more in the city than in suburbia).

The long-term residents and the newcomers may have the same everyday practices but perform them in different mode. In particular, while newcomers understand leisure time as visiting fashionable restaurant, going to the cinema with friends, or watching night skies in a telescope on the lawn near the house, for the long-term residents "leisure time" is often reduced to housework, work in the garden or vegetable plot, fishing on the local pond, or just drinking beer in the local hole-in-the-wall. A long-term resident is used to buy vegetables and fruits in an old Soviet-style grocery, while a newcomer, if decide not going to the city, visits for the same purpose a recently open urban-style minimarket, etc. Even for commuting they are using different means of transport: while the newcomers give preferences to personal cars, the long-term residents typically use "marshrutkas". Like the long-term residents, the newcomers socialise with friends, do sports and spend time with children mostly in Ahronomichne, but these practices take place within confined private spaces, such as in a fenced yard of a detached homestead or cottage. The most public spaces of the village are rarely used by the newcomers because they do not meet their needs: they are badly organised, have typical "rural" aesthetics, and often serve as a place for unregulated street trade or drinking, etc. (Fig. 5).

Finally, differences are visible in self-identification and perception of life in suburbia. While most long-term residents identify themselves as rural inhabitants and link own identity to Ahronomichne, the majority of newcomers identify themselves as suburban residents and prefer to underline their link to the central city rather than to the "unknown suburban village", a "bedroom community" (quotations from the interview NC-02). The perceived inconveniences also reflect differences in lifestyles, values, and identities: while long-term residents are preoccupied about the lack of employment opportunities and poor social infrastructure (which indicates their rootedness in the village), newcomers worry most about the problems with commuting to the city and lack of places for recreation and leisure in suburbia (which indicates their orientation to the city and simultaneously the desire to "bring the city to the suburbia"). Symptomatically, high rates of new housing construction are disturbing the long-term residents much more than the newcomers:
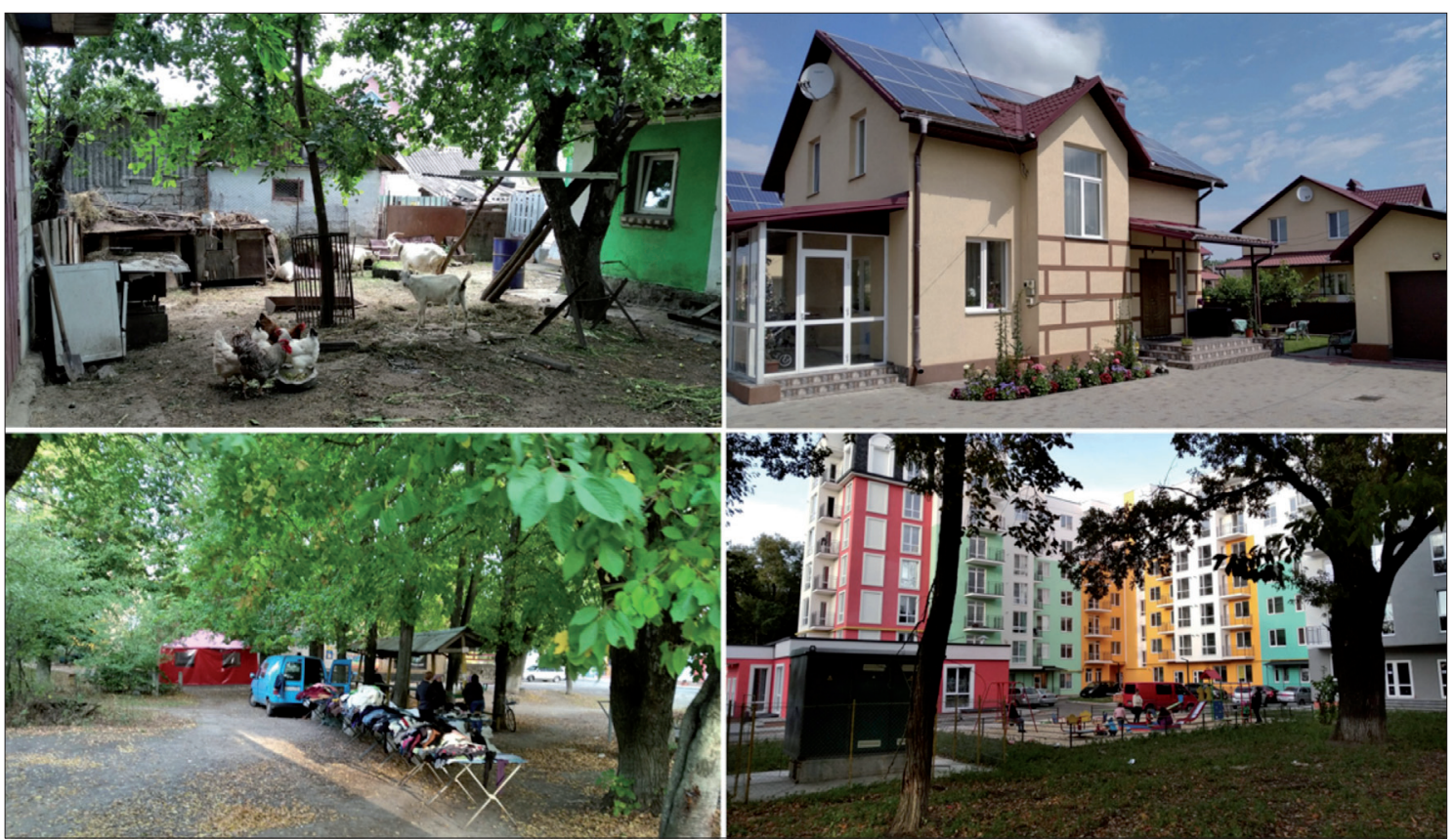

Fig. 5: Divided everyday practices in Ahronomichne (from the upper left clockwise: backyard of the long-term resident's house; outdoor space in the cottage town; recreation with children near the newly-build apartment house; unregulated trade in the old part of the village)

Source: Photos by Oleksiy Gnatiuk (2019-2020) 
"The attitude [to the new housing] is negative. Of course, in the village council they will tell you that it is good: investors, taxes, landscaping. But we don't need all that. We need peace. Constantly transport, trucks go on the road, nowhere to hide from the noise. The load on kindergarten and school is growing. New houses are connected to the old water supply system - it is not designed for that. And landscaping... Look at my house! Behind the fence is the area of responsibility of the village council. Did they mow the grass there at least once? We do everything ourselves. Yes, there are several new shops, there is a pharmacy... but in general nothing is developing in the village. Instead, they build up every free piece of land. This is a big business... Those cottages are built on the former lands of our research station." (Informant LTR-01)

It could be seen that the informant is concerned about both the deterioration of quality of life and the loss of the local identity tied to the research station. The attitude to the newcomers often is also far from being friendly:

"They all are strangers, capitalists, pests. Here they have more comfortable life: quietness, calmness. But they are in Vinnytsia all the time. They work there, they just sleep here. We do not communicate with them. And no one will let in there because of dogs, fences..." (Informant LTR-01)

This unfriendly attitude to the newcomers is enhanced by the trampled pride of the former and current agricultural station employees. In the past, they did important scientific work that was in demand by the economy, but nowadays it seems that no one needs them:

"The station was engaged in selection. Varietal seeds were grown for the whole region. Look - the beets are shooting now, and why? Because it is not a varietal seed. And then there was a distribution list: all kolkhozes received our varietal seeds - wheat, oats, barley, beets. Wheat yield was $70-100 \mathrm{~kg} / \mathrm{ha} . .$. And now sunflower and rapeseed are planted for big profits, but those crops exhaust the soil" (Informant LTR-02)

Some newcomers are also worried about the continuing construction in Ahronomichne, but their principal reason is to save existing benefits of suburban life:

"The construction is normal thing. The village is developing, this process cannot be stopped, and it is inexpedient to stop. But it should be a controlled development, so that those who already live here could influence what and where to build. There may be highrise buildings, but their number should be limited. The preference should be for low-rise development, in order to keep the benefits of local life." (Informant NC-01)

Concerning the vision of the future of the suburbia, it seems that the line of division split the newcomers by type of housing. While inhabitants of detached houses and cottages have joined the long-term residents in their desire to keep the administrative independence of the village from the city, the inhabitants of apartment houses do not see alternatives to the absorption by the city:

"Of course, we must remain independent. We need peace, tranquility, the ability to manage the land on our own. Vinnytsia, what good is it to us? It will be a new split-up of the land plots. Housing prices and living costs will jump immediately." (Informant LTR-01)

"I am for a strong and independent local government. There must be patriots in power who are able to defend the interests of the village community. Interest in land, for example. But cooperation can and should be agreed with the city. You can't run away from this." (Informant NC-01, cottage resident)

"I see no alternative to merging with the city. In fact, it is already half an urban neighbourhood, although very remote. All work in the city, study in the city. It is necessary to legalise what has already happened." (Informant NC-02, resident of the apartment house)

It may be concluded that Ahronomichne is divided in terms of everyday practices, self-identifications and perceptions. The long-term residents are still keeping mostly rural lifestyle and rural identity; the newcomers live mostly classical suburban city-oriented lifestyles and consider the village as a bedroom community, consequently falling out of the social life of the settlement. In fact, co-education of children in local secondary school and kindergarten is the unique social practice that promotes communication between the two groups of residents.

\subsection{Mixing and hybridising everyday practices and lifestyles}

Despite the existing divisions between the old and new suburban residents, we found also mutual interactions of lifestyles and everyday practices (1) of the long-term residents and newcomers and (2) the residents of different type of development, primarily detached houses from one side and multy-storey apartment houses from the other. These interactions result in mixing and hybridisation of everyday practices and, consequently, lifestyles. Mixing is a simultaneous coexistence of different lifestyles and practices in suburbia, while hybridisation is when a person (or household) combines different practices and lifestyles so that is impossible to define the exact type of lifestyle (urban, suburban, or rural).

Rural environment makes an imprint on the housing practices of the newcomers. A lot of the new households have such traditional rural elements of homesteading like a cellar, barn, vegetable plot, garden, and poultry. Interestingly, this refers not only to the residents of detached houses, but to those living in apartment houses as well. It is important to emphasise here that improvised gardens kept near the highrise apartment buildings is a quite common phenomenon on post-Soviet space, including for the large cities and their mass housing neighbourhoods; in the urban environment, these gardens usually include flowerbeds, vegetable plots and several fruit trees. Nearly $30 \%$ of the newcomers identify themselves as rural residents, and almost $40 \%$ of them would indicate Ahronomichne, not the city, as their residential place. Despite the fact that the newcomers use personal cars for commuting much more often comparing with the longterm residents, public transport ("marshrutkas") appears to be the most important mean for commuting in both groups. In relation to the adoption of rural practices, the lifestyles of newcomers may be divided into:

1. "wealthy suburbanism" of detached houses and cottages, which, on the one hand, are more socially closed within their own backyards, but on the other, actively adopt certain rural housing practices, and

2. "suburbanism of apartment houses", who are more active in using suburban public spaces but have fewer opportunities to acquire rural housing practices; this is the most "urbanised" part of residents in terms of lifestyle.

And vice versa, long-term residents are adopting urban/ suburban lifestyles of the newcomers. They try to modernise their houses and fences with fashionable materials, 
introduce western-looking grass lawns instead of the classical rural flowerbed, replace classical gardens for wall or dwarf gardens that initially have been hallmarks of the new households. Also, only a third of the long-term households keep cattle, which is small figure for a typical Ukrainian village. Although the long-term residents are less dependent on the city, they acquire the taste of living near a big city and using its benefits: nearly a half of them indicated lack of places for recreation and leisure, which is not much less than among the newcomers. Despite the dominance of rural self-identification, every forth long-term resident declared urban or suburban identity, and nearly a half of them would prefer Vinnytsia to Ahronomichne answering the question "Where are you from?" Even some natives of the village considered themselves to be "urban" residents. The figures from the Table 2 are convincing that some of their everyday practices (purchase of non-food products, visiting cultural institutions, beauty industry and health care institutions) are strongly linked to the city, and another set of practices are more or less equally distributed between the suburbia and the city (work, education, purchase of food products, visiting catering facilities).

The hybridisation of everyday practices in the same household and the age shift from rural to suburban lifestyle with a change of generation is readable from the following interview fragment:

\section{"Would you like to move to Vinnytsia?}

No. And my daughter wouldn't move either. We are not used to living in an apartment. We got used to the own house, to the nature, to the garden. Here you feel the ground under your feet.

You and your daughter run a farm and work in the garden, and the granddaughter?

Granddaughter is not the case! She has never worked in the garden and will not work. Her maximum is to bring water and pour on something. She is in a performance ensemble, she dances, she needs her hands to be beautiful.
She has all the business in Vinnytsia. She studies there, meets her friends there, she walks there, cinemas and all these things... She likes being here [in Ahronomichne], but she only sleeps and eats here. She says: 'I will not tear weeds, I need to earn money.'” (Informant LTR-01)

The penetration of typically urban structures and services to the village is stressed by the facts that (1) in 2018 the village administration moved to a new office on the ground floor of the 7-storey apartment house, a unique situation for Ukrainian village, being a good illustration of its suburban situation; (2) a centre for administrative services, providing 37 different services, including issuance of passports for travelling abroad, was opened in the same building; this was the first institution of this type in Ukraine located in the formally rural area (Fig. 6).

Therefore, we can conclude that the long-term residents are gradually changing their traditional rural way of life, enriching it with several suburban elements. If we imagine that the new residential development in Ahronomichne suddenly disappeared, the remaining settlement would not be unambiguously rural in term of visual appearance and lifestyle of the inhabitants. This is a typical rural suburbanism of a peri-urban village, caused by the destruction of the traditional rural economic base (in our case - research station) and the proximity to the city as a powerful labour market, a source of various high-quality services, a magnet of urban lifestyles.

To some extent, we can assume that long-term residents and newcomers are characterised by "parallel lives." Moreover, the othering of newcomers can be projected onto the othering of spaces that they occupy (Woods and Kong, 2020). Such "spatial parallelism" in suburbia of the second-order city has some visible physical manifestations, in particular concerning area arrangement, composition of homesteading, and mobility. The study also revealed sociocultural differences in dweller's behaviour, from their selfidentification (e.g. suburban vs. rural), everyday practices (e.g. different work or leisure sites preferences) to possible

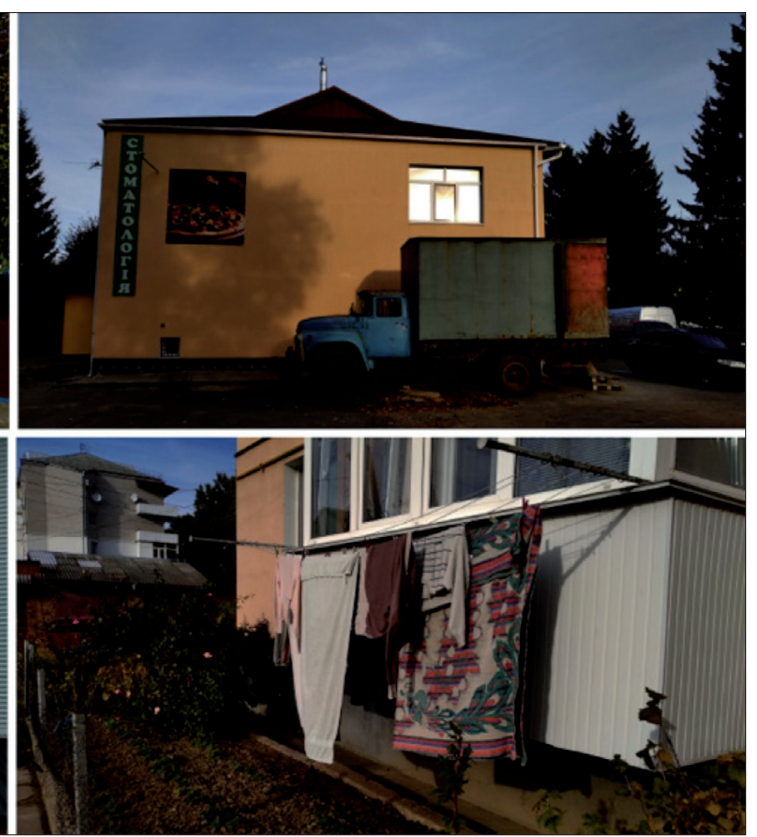

Fig. 6: Mixing everyday practices in Ahronomichne (from the upper left clockwise: partially "modernised" old homestead; old truck serving as a trade warehouse in front of recently opened trattoria and dentistry; strawberry beds near the multi-storey apartment house; entrance to the centre for administrative services and ATM)

Source: Photos by Oleksiy Gnatiuk (2019) 
misunderstandings and prejudice. We should also keep in mind that in an era of liquid migration (Engbersen, 2018) migrations of newcomers can be fluid, and therefore suburban community has a plural expression of place attachments, a complicated configuration of relationships between "roots" (fixities) and "routes" (mobilities) (Di Masso, 2019).

\section{Conclusions}

The study of the everyday practices, self-identities and perceptions seems to be a promising approach to understand the suburbia and suburban spaces as not only static containers but as socially constructed, dynamic and ambiguous entities. Everyday practices in Ahronomichne, representing peri-urban village near the second-order Ukrainian city, differ in terms of their set, spatial configuration and mode of performance. The trajectory of changing lifestyles in the suburbia is drastically defined by the western-type pattern of suburban growth, and that is why the main watershed lies among the long-term residents and the newcomers, the initial bearers of typically rural and typically urban lifestyles respectively. The other factors are type of housing, which determines a particularly high level of diversity of everyday practices in suburban village, as well as age and family status. Consequently, the suburbia comprises a combination of modern features of the urban lifestyle and traditional components of the rural lifestyle (Castle, Wu and Weber, 2011); by means of suburbia, urban and rural areas become "connected vessels" (Drobyshevskaia, 2005). However, it is impossible to state unequivocally about the expansion or contraction of everyday practices, but rather about their gradual transformation, intertwining, mixing and hybridisation (see also Mezentsev et al., 2019; Mezentsev and Provotar, 2020). Accordingly, the suburban spaces enhance their internal diversity and patchiness.

Located near the second-order city outside global urban centres, relatively insulated from urbanisation, former typical rural settlement Ahronomichne now is engulfed by territorial expansion of "a planetary formation of urbanisation" (Brenner and Schmid, 2015). While this suburbia is still quite unevenly captured by urbanisation, it is distinctly more interwoven in urban fabric. Newcomers bring new features to rural area contributing in turn to the production of new (more urbanised) forms of everyday practices.

Can the patterns of the case be extrapolated onto the overall territory of Ukraine? The distinct identity of the research station employees may be considered as a specific feature of Ahronomichne. On the one hand, this identity encourages long-term residents to keep the traditional way of life, but on the other, specific built environment of the village (e.g. presence of the apartment houses already during the Soviet era) facilitates the adoption of typical urban lifestyles. These factors work in opposite directions, and that is why our findings with regard to the mixing and hybridising everyday practices and lifestyles may be extended to most other villages at the urban fringes of large cities (with population of $100,000-500,000$ ) in the central part of the country. The same refers to the revealed motivations of contemporary migrants to suburbia, which is partially supported by the existing literature on Ukrainian cities compared to Vinnytsia in terms of population (e.g. Zakutynska and Slyvka, 2016) At the same time, the conclusions should be applied more delicately to suburban settlements in other regions of the country (e.g. Western of Eastern Ukraine, as Ukraine is very diversified country in terms of historical and cultural background, as well as current migration patterns), as well as to other types of suburbia (e.g. satellite towns) and other types of the central cities (e.g. the largest metropolises like Kyiv). In particular, there is evidence that suburban fringe of Kyiv shows quite different origin and motivation of suburban migrants (Mezentsev et al., 2020).

Taking into account the above presented results, as well as the findings of the previous recent researches on Vinnytsia and other Ukrainian cities (Gnatiuk, 2017; Zakutynska and Slyvka, 2016; Havryliuk et al., 2021), it is possible to assert that the most economically vibrant large cities in Ukraine have already switched to the suburbanisation stage of urban development (van den Berg, 1999). In particular, rapid suburban development in Ahronomichne was triggered by the factors like the decline of large scale industries, rise of services, certain increase in welfare and private car ownership, as well as the increased appreciation of the living environment. In this sense, the findings support the mainstream stages of urban development model both in numerical figures reflecting migration dynamics and in respect to underlying factors. However, the suburbia may show significant internal diversity even in case of not too big city, which is Vinnytsia. For example, demographic growth in Ahronomichne occurs together with the very weak commercial suburbanisation, while some other suburban villages near Vinnytsia (e.g. Zarvantsi, Iakushyntsi - see Fig. 2) thrive precisely because of the location of large network shopping centres, car repair services, and logistics. In this sense, different settlements within the same suburban area may show different patterns of development depending on their location relative to highways, attractive natural landscapes, local identity, etc.

To summarise, the accented heterogeneity and fragmentation of post-Soviet suburbia is observed even when the process of suburban development generally corresponds to the classical western-type suburbanisation. This is due to the original genetic differences of suburban areas and the spatial selectivity of contemporary suburban development. The suburbs of post-communist cities cannot be considered as a homogeneous formation, but rather as a patched environment and simultaneously a product of the urbanrural interaction, their intertwining, accompanied by the erosion of old identities of the suburban settlements and the formation of new "hybrid" identities. This internal diversity and ambiguity is especially noticeable when complementing the functions and forms of the build environment with the analysis of everyday practices and self-identifications of residents, and the latter can be decisive for the further trajectory of suburban development. Significant level of urban-rural socio-economic disparities in post-communist Europe contributes to the formation of particularly striking forms of interaction, each of which represents a separate version of "suburbanism" as a socio-spatial phenomenon. This means the complexity, nonlinearity and heterochrony of the transition from suburbia to post-suburbia in the postcommunist space.

An outside observer, knowing Ahronomichne only from the media, may conclude that it is currently near the end of a single direction route from the agricultural research station to a "luxury village". However, unweaving a tangled skein of everyday practices, identities and perceptions of the villagers, we see neither single direction route nor the end of the journey. Rather, we detect a complex system of highways, alleys and winding paths in between the agricultural station village, the suburban "luxury village" and the urban 
neighbourhood. The understanding of this complexity should keep the urban planners from simple straightforward planning decisions with regard to suburban spaces: the latter need balanced development aimed at the formation of a social mix as a basis for the resilience of suburban communities to the socio-economic challenges of today.

\section{Acknowledgements}

The research was funded by the Ministry of Education and Science of Ukraine in the framework of the joint UkrainianAustrian project No. $0120 U 104700$ "Ambiguous suburban spaces: Comparative analysis of local trajectories and changing everyday practices". The authors are thankful to the editor and two anonymous reviewers for their valuable comments, which helped to improve the manuscript, and would like to pay their gratitude to the anonymous informants for sharing their experiences, attitudes and intimate stories.

\section{References:}

AERO, T. (2006): Residential choice from a lifestyle perspective housing. Theory and Society, 23(2): 109-130.

AMATO, P. R. (1993): Urban-rural differences in helping friends and family members. Social Psychology Quarterly, 56(4): 249-262.

ANDERSON, K. (2006): Introduction: after sprawl: postsuburban Sydney. In: Anderson, K., Dobson, R., Allon, F., Neilson, B. [eds.]: E-Proceedings of 'Post-Suburban Sydney: The City in Transformation' Conference, Sydney.

BORÉN, T., GENTILE, M. (2017): Metropolitan processes in post-Communist states: an introduction. Geografiska Annaler, Series B: Human Geography, 89(2): 95-110.

BOURNE, L. S. (1996): Reinventing the suburbs: old myths and new realities. Progress in Planning, 46(3): 163-184.

BRENNER, N., SCHMID, C. (2014): The 'Urban Age' in Question. International Journal of Urban and Regional Research, 38(3): 731-755.

BRENNER, N., SCHMID, C. (2015): Towards a new epistemology of the urban? City, 19(2-3): 151-182.

CASTLE, E., WU, J., WEBER, B. (2011): Place orientation and rural-urban interdependence. Applied Economic Perspectives and Policy, 33: 179-204.

CHESHIRE, P., HAY, D. G. (1989): Urban Problems in Western Europe - An Economic Analysis. London, Unwin Hyman.

DAVIDSON, M., LEES, L. (2005): New-build "gentrification" and London's riverside renaissance. Environment and Planning A, 37: 1165-1190.

DENYSYK, G., MEZENTSEV, K., ANTIPOVA, E., KIZIUN, A. (2020): Heohrafija povsiakdennia: prostorove riznomanittia povsiakdennoho zhyttia. Visnyk of V. N. Karazin Kharkiv National University, Series Geology. Geography. Ecology, 52: 130-138.

DEN HARTOG, H. [ed.] (2006): Exurbia/Wonen buiten de stad. Rotterdam, Episode Publishers.

DI MASSO, A., WILLIAMS, D. R., RAYMOND, C. M., ... VON WIRTHM, T. (2019): Between fixities and flows: Navigating place attachments in an increasingly mobile world. Journal of Environmental Psychology, 61: $125-133$
DROBYSHEVSKAJA, T. (2005): Osnovy gorodskoj politiki. Donetsk, Jugo-Vostok.

DRUMMOND, L., LABBÉ, D. (2013): We're a long way from Levittown, Dorothy: everyday suburbanism as a global way of life. In: Keil, R. [ed.]: Suburban Constellations: Governance, Land and Infrastructure in the $21^{\text {st }}$ Century (pp. 46-51). Berlin, Jovis.

DUIJZINGS, G. (2013): Introduction. In: Duijzings, G. [ed.]: Global villages: rural and urban transformations in contemporary Bulgaria (pp. 1-32). London, Anthem Press.

DYMITROW, M., STENSEKE, M. (2016): Rural-urban blurring and the subjectivity within. Rural Landscapes: Society, Environment, History, 3(1): 1-13.

ENGBERSEN, G. (2018): Liquid Migration and its Consequences for Local Integration Policies. In: Scholten, P., van Ostaijen, M. [eds.]: Between Mobility and Migration. IMISCOE Research Series (pp. 63-76). Springer, Cham.

EYLES, J. (1989): The geography of everyday life. In: Gregory, D., Walford, R. [eds.]: Horizons in Human Geography (pp. 102-117). London, Macmillan.

FAVA, S. F. (1956): Suburbanism as a way of life. American Sociological Review, 21(1): 34-37.

FEIJTEN, P., HOOIMEIJER, P., MULDER, C. H. (2008): Residential experience and residential environment choice over the life-course. Urban Studies, 45: 141-162.

FISHER, T. (2003): Differentiation of growth processes in the peri-urban region: an Australian case study. Urban Studies, 40(3): 551-565.

FORD, T. (1999): Understanding population growth in the peri-urban region. International Journal of Population Geography, 5(4): 297-311.

GARREAU, J. (1991): Edge City: Life on the New Frontier. New York, Doubleday.

GEYER, H., KONTULY, T. (1993): A theoretical foundation for the concept of differential urbanization. In: Hermanus, G., Kontuly, T. [eds.]: Differential Urbanization: Integrating Spatial Models (pp. 290-308). London, UK, Edward Arnold.

GHOSE, R. (2004): Big sky or big sprawl? Rural gentrification and the changing cultural landscape of Missoula, Montana. Urban Geography, 25(6): 528-549.

GNATIUK, O. (2016): Dakhy z suchasnykh materialiv jak marker modernizatsijnoho vplyvu mista na prymis'ku zonu (pryklad Vinnytsi). Chasopys kartohrafiji, 16: 39-47.

GNATIUK, O. (2017). Demographic dimension of suburbanization in Ukraine in the light of urban development theories. Acta Universitatis Carolinae Geographica, 52(2): 13-25.

GOLUBCHIKOV, O., PHELPS, N.A., MAKHROVA, A. (2010): Post-socialist post-suburbia: growth machine and the emergence of "edge city" in the metropolitan context of Moscow. Geography, Environment, Sustainability, $3(1)$ : 44-54.

HARRIS, R. (2010): Meaningful types in a world of suburbs. Research in Urban Sociology, 10: 15-47.

HAVRYLIUK, O., GNATIUK, O., MEZENTSEV, K. (2021): Suburbanization, but centralization? Migration patterns in the post-Soviet functional urban region - evidence from Kyiv. Folia Geographica, 63(1): 64-84. 
HEIJS, W., CARTON, M., SMEETS, J., VAN GEMERT, A (2009): The labyrinth of life-styles. Journal of Housing and the Built Environment, 24: 347-356.

HIRT, S. (2007): Suburbanizing Sofia: characteristics of post-socialist peri-urban change. Urban Geography, 28(8): 755-780.

HUKALOVA, I. (2009): Jakist' zhyttia naselennia Ukrajiny: suspil'no-heohrafichna kontseptualizatsija. Kyiv, Drukarnia MVS Ukrajiny.

JANSEN, S. J. T. (2020): Urban, suburban or rural? Understanding preferences for the residential environment. Journal of Urbanism: International Research on Placemaking and Urban Sustainability, 13(2): 213-235.

KANEFF, D. (2013): Rural-urban relations in a global age. In: Duijzings, G. [ed.]: Global villages: rural and urban transformations in contemporary Bulgaria (pp. 33-51). London, Anthem Press.

KEIL, R. (2018): Suburban Planet: Making the World Urban from the Outside in. Cambridge, Polity Press.

KRISJANE, Z., BERZINS, M. (2012): Post-socialist urban trends: new patterns and motivations for migration in the suburban areas of Riga, Latvia. Urban Studies, 49(2): 289-306.

KUBEŠ, J., NOVÁČEK, A. (2019): Suburbs around the Czech provincial city of České Budějovice - territorial arrangement and problems. Hungarian Geographical Bulletin, 68: 65-78.

LEETMAA, K., TAMMARU, T., ANNISTE, K. (2009): From priority-led to market-led suburbanisation in a postCommunist metropolis. Tijdschrift voor Economische en Sociale Geografie, 100(4): 436-453.

LE GATES, R., STOUT, F. [eds.] (1996): The City Reader. London - New York: Routledge.

MALCHYKOVA,D.,PYLYPENKO,I.(2017):Vid “rozirvanoho" prostoru do metropolizaciji i suburbanizacii: Khersonska miska ahlomeracija u novykh vymirakh urbohenezu. In: Mezentsev, K., Olijnyk, Ya., Mezentseva, N., [eds.]: Urbanistychna Ukrajina: V Epitsentri Prostorovykh Zmin (pp. 326-338). Kyiv, Fenix.

MANSHYLINA, T. (2015): Suspil'no-heohrafichne doslidzhennia rozvytku mist-suputnykiv ta prymiskoji zony Kyjeva. Abstract of a PhD Thesis. Kyiv, Taras Shevchenko National University of Kyiv.

MANTEY, D., SUDRA, P. (2019): Types of suburbs in postsocialist Poland and their potential for creating public spaces. Cities, 88: 209-221.

MASSOTTI, L. H. (1973): Prologue: suburbia reconsidered myth and counter-myth. In: Masotti, L. H., Hadden, J. K. [eds.]: The Urbanization of the Suburbs (pp. 15-22). London, Sage.

MATLOVIČ, R., SEDLÁKOVÁ, A. (2007): The impact of suburbanization in the hinterland of Prešov (Slovakia) Moravian Geographical Reports, 15(2): 22-31.

MATZ, C. J., STIEB, D. M., BRION, O. (2015): Urban-rural differences in daily time-activity patterns, occupational activity and housing characteristics. Environmental Health, 14: 88

MCMANUS, R., ETHINGTON, P. (2007): Suburbs in transition. New approaches to suburban history. Urban History, 34(2): 317-337.
MEZENTSEV, K. (2017): Vstup: prymis'ki prostory, scho zminiujut'sia ta vynykajut'. In: Mezentsev, K., Oliynyk, Ya. [eds.]: Urbanistychna Ukrajina: V Epitsentri Prostorovykh Zmin (pp. 261-267). Kyiv, Fenix.

MEZENTSEV, K., HAVRYLIUK, O. (2015): Testuvannia modeli dyferencial'noji urbanizaciji $\mathrm{V}$ Ukrajini. Ekonomichna ta Sotsialna Geografija, 73: 15-26.

MEZENTSEV, K., MEZENTSEVA, N. (2017): Zhytlova suburbanizacija v Ukrajini: trendy ta vidminnosti. In: Mezentsev, K., Olijnyk, Ya., Mezentseva, N., [eds.]: Urbanistychna Ukrajina: V Epitsentri Prostorovykh Zmin (pp. 268-287). Kyiv, Fenix.

MEZENTSEV, K., PROVOTAR, N. (2020): Neodnoznachni prymis'ki prostory: rozshyrennia chy zvuzhennia povsiakdennykh praktyk? In: Berghauer, S., Dnyisztrjanszkij, M., Gyula, F. [eds.]: Human Geographical Processes in East-Central Europe: Problems, Tendencies and Trends, Vol. 1 (pp. 41-46). Uzhhorod.

MEZENTSEV, K., PROVOTAR, N., GNATIUK, O., MELNYCHUK, A., DENYSENKO, O. (2019): Neodnoznachni prymis'ki prostory: tendentsiji ta osoblyvosti zminy povsiakdennykh praktyk. Ekonomichna ta Sotsialna Geografija, 82: 4-19.

MEZENTSEV, K., PROVOTAR, N., GNATIUK, O., MELNYCHUK, A., DENYSENKO, O. (2020): Trajektoriji rozvytku prymis'kykh prostoriv. Scientific Bulletin of Kherson State University - Geographical Sciences, 13: $63-75$.

MOKHTARIAN, P., CAO, X. (2008): Examining the impacts of residential self-selection on travel behaviour: a focus on methodologies. Transportation Research B, 42: 204-228.

NEFEDOVA, T. G. (2018): The Moscow suburbs: specifics and spatial development of rural areas. Regional Research of Russia, 8(3): 225-237.

OUŘEDNÍČEK, M. (2007): Differential suburban development in Prague urban region. Geografiska Annaler, Series B: Human Geography, 89(2): 111-126.

PISMAN, A., ALLAERT, G., LOMBAERDE, P. (2011): Urban and suburban lifestyles and residential preferences in a highly urbanized society. Experiences from a case study in Ghent (Flanders, Belgium). Belgeo, 1-2: 89-104.

PHELPS, N. A. (2017): Introduction: Old Europe: New Suburbanization? In: Phelps, N. A. [ed.]: Old Europe: New Suburbanization. Governance, Land and Infrastructure in European Suburbanization (pp. 3-17). Toronto, University of Toronto Press.

PHELPS, N.A., TARAZONA VENTO, A., ROITMAN, S. (2015): The suburban question: grassroots politics and place making in Spanish suburbs. Environment and Planning C: Government and Policy, 33(3): 512-532.

PROVOTAR, N., MELNYCHUK, A., GNATIUK, O., DENYSENKO, O. (2019): Minlyvi povsiakdenni praktyky u prymis'kykh prostorakh: metodyka doslidzhennia mistsevykh trendiv. Ekonomichna ta Sotsialna Geografija, 81: 34-41.

REIJNDORP, A. (2004): Stadswijk. Stedenbouw en Dagelijks Leven. Rotterdam, NAi Uitgevers.

REIJNDORP, A., KOMPIER, V., METAAL, S., NIO, I., TRUIJENS, B. (1998): Buiten Wijk. Stedelijkheid op Afstand. Rotterdam, NAi Uitgevers. 
SCHNEIDER, W. (1992): The suburban century begins. Atlantic Monthly, July 1992: 33-44.

SHEN, J., WU, F. (2013): Moving to the suburbs: demandside driving forces of suburban growth in China. Environment and Planning A, 45(8): 1823-1844.

SLAEV, A. D., KOVACHEV, A. (2014): Specific issues of urban sprawl in Bulgaria. European Spatial Research and Policy, 21(2): 155-169.

STANILOV, K., SÝKORA, L. [eds.] (2014): Confronting Suburbanization: Urban Decentralization in Postsocialist Central and Eastern Europe. Oxford, Wiley-Blackwell.

TAMMARU, T. (2001): Suburban growth and suburbanisation under central planning: the case of Soviet Estonia. Urban Studies, 38(8): 1341-1357.

VAN ACKER, V. (2010): Spatial and Social variations in Travel Behaviour. Incorporating Lifestyles and Attitudes into Travel Behaviour-Land Use Interaction Research. Zelzate, University Press.

VAN DEN BERG, L. (1999): The urban life cycle and the role of a market-oriented revitalization policy in Western Europe. In: Summers, A. A., Cheshire, P. C., Senn, L. [eds.]: Urban Change in the United States and Western Europe: Comparative Analysis and Policy (pp. 539-558). Washington, D.C.,The Urban Institute Press.
VAN DEN BERG, L., DREWETT, R., KLAASSEN, L. H., ROSSI, A., VIJVERBERG, N. H. T. (1982): A study of growth and decline. Oxford, Pergamon.

WALKER, J. L., LI, J. (2007): Latent lifestyle preferences and household location decisions. Journal of Geographical Systems, 9(1): 77-101.

WALKS, A. (2013): Suburbanism as a way of life, slight return. Urban Studies, 50(8): 1471-1488.

WOODS, O., KONG, L. (2020): Parallel spaces of migrant (non-)integration in Singapore: Latent politics of distance and difference within a diverse Christian community. Journal of Intercultural Studies, 41(3): 339-354.

ZAKUTYNSKA, I., SLYVKA, R. (2016): Suburbanizatsija v prostorovomu vymiri: Ivano-Frankivs'k i joho okolytsi. Kyiv, Lohos.

\section{Please cite this article as:}

GNATIUK, O., MEZENTSEV, K., PROVOTAR, N. (2021): From the agricultural station to a luxury village? Changing and ambiguous everyday practices in the suburb of Vinnytsia (Ukraine). Moravian Geographical Reports, 29(3): 202-216. doi: https://doi.org/10.2478/mgr-2021-0015 